\title{
In school we have not time for the future: voices of Swedish upper secondary school students about solidarity and the future
}

\section{Tomas Torbjörnsson \& Lena Molin}

To cite this article: Tomas Torbjörnsson \& Lena Molin (2015) In school we have not time for the future: voices of Swedish upper secondary school students about solidarity and the future, International Research in Geographical and Environmental Education, 24:4, 338-354, DOI: 10.1080/10382046.2015.1086105

To link to this article: $\mathrm{http}: / / d x . d o i . o r g / 10.1080 / 10382046.2015 .1086105$

Published online: 13 Oct 2015.

Submit your article to this journal $\llbracket$

III Article views: 13

View related articles ־

View Crossmark data $\asymp$ 


\title{
In school we have not time for the future: voices of Swedish upper secondary school students about solidarity and the future
}

\author{
Tomas Torbjörnsson ${ }^{\mathrm{a} *}$ and Lena Molin ${ }^{\mathrm{b}}$ \\ ${ }^{a}$ The Center for Teaching and Learning in the Social Sciences, Stockholm University, Edsviken \\ Nybacka, 66691 Bengtsfors, Stockholm, Sweden; ${ }^{b}$ Department of Education, Uppsala University, \\ Östra Sund 230, 71391 Nora, Uppsala, Sweden
}

\begin{abstract}
The present article presents results obtained from a survey focusing on attitudes to solidarity among upper secondary school students. A relation between positive attitudes to solidarity and future-orientation was evident. The survey results were reinforced by a second study, exploring how students in the Swedish upper secondary school perceived the value solidarity, and whether the future-dimension was reflected in teaching. Twenty-two third-year students attending theoretical and vocational programmes at five upper secondary schools were interviewed. After coding and transcribing, a thematic analysis was performed, categorizing the interview responses into sub-themes, representing different aspects of solidarity and future-orientation. The analysis revealed that these students were not acquainted with solidarity as a concept. In the cases solidarity had been brought up at all in class, the students primarily contemplated it in a historical context. Notwithstanding, several students expressed a definite ambition and readiness to act in a solidary manner in order to contribute to improved social and ecological justice, also in relation to future generations. The interviews furthermore disclosed that teaching rarely had included the future-dimension; the students considered the future to be an individual rather than a shared challenge. In terms of resolving future challenges, such as the climate threat, their confidence in natural scientists and technologists was high, but few students conveyed trust in politicians, or believed that school, teachers, and students would take on an active role. Conclusively, activating the future-dimension in the Education for Sustainable Development (ESD) might be a means to ameliorate the preconditions for youths' environmental moral learning.
\end{abstract}

Keywords: upper secondary school students; environmental moral learning; solidarity; future-dimension; ecological citizenship; Education for Sustainable Development (ESD)

\section{Introduction}

Close to three decades ago, the concept sustainable development was launched (WCED, 1987) to explicate how social, economic, and ecological dimensions must be balanced in order to guarantee acceptable living conditions for future generations. Principles for sustainable development have now been implemented globally in companies, authorities, and schools. There are great expectations that Education for Sustainable Development (ESD) will rigorously change the education, "enforcing the necessary adjustments of society, and find solutions to the economic, social, and environmental challenges facing the world" (The Swedish National Commission for UNESCO, 2014). Although ESD has been formally implemented in the school systems of most countries (Wals, 2009), a genuine transition towards global sustainable development (Tilbury, 2012) is still at want.

*Corresponding author. Email: Tomas.torbjornsson@cesam.su.se 
Solidarity being a fundamental sustainability value (Leiserowitz, Kates, \& Parris, 2006; UN, 2000), and future-orientation being a self-evident aspect of sustainable development, lends pertinence to the relation between solidarity and future-orientation. Torbjörnsson and Molin (2014) found future-orientation to be a predictor of solidarity. The purpose of the present study was to explore how the value solidarity and the future-dimension were reflected in teaching in a Swedish context. The research questions focused on how students perceived the future-dimension and the value solidarity, and whether discussions reflecting on these themes had been incorporated into the teaching during their 12 years of education.

\section{The Swedish context}

The portal paragraph in the Swedish Education Act justified the present study, as it postulates that the aim of education is "to acquire and develop knowledge and values." One explicit value constitutes solidarity among people (Skollag 2010:800, 1 kap, §5). Establishing international, environmental, ethical, and historical perspectives is a fundamental task for the Swedish school within all education. The international perspective aims at "An international perspective is important to be able to understand one's own reality in a global context and in order to create international solidarity" (Skolverket, 2011a). It is mandatory for teachers to incorporate ESD into all subjects, but in geography a more explicit responsibility has been assigned. In compulsory school, the teaching of geography shall, as one of four aims, develop the students' skill and ability to "assess solutions to different environmental and development issues, based on considerations concerning ethics and sustainable development" (Skolverket, 2011b, p. 151). The geography syllabus in upper secondary school has been given a similar aim: to develop the "ability to reflect on how people in their everyday lives can contribute to sustainable development" (Skolverket, 2011c). Geography is compulsory in primary school, ages 7-16. In upper secondary school, however, geography is taught only to students in the social sciences programmes (approximately $20 \%$ of all students).

After 9 years in compulsory school, almost all Swedish students continue their studies in one of the 16 national programmes in upper secondary school. Most of them complete their baccalaureate at the age of $18-19$ years, but there is a dropout rate ranging from $5 \%$ to $20 \%$ in different programmes and regions.

\section{Theoretical framework}

\section{The concept of solidarity}

Although solidarity is manifested as fundamental to sustainable development, the interpretation of the concept is rarely problematized (Sleeter \& Soriano, 2012). Historically, solidarity has implied mutual obligations and assurances within some form of community, and citizenship has traditionally been defined as belonging to such a community. Solidarity has thus primarily been reserved for citizens sharing a community, hence being delimited in time and space. With the implication of citizenship now being challenged by political theoretics who argue that globalization and striving for sustainable development require another outlook on citizenship, Dobson $(2003,2007)$ suggested the term ecological citizenship. This perspective diverts from the traditional citizenship by accentuating responsibility rather than rights and is not restricted to present citizens within a specific 
community or nation. The presumption is that how we live our lives will have a number of cross-border effects on people, species, and places, presently as well as in the future, and locally as well as globally. Consequently, we have a responsibility to minimize negative effects, and this responsibility is not restricted in time or space. Ecological citizenship thus refers to the ecological footprint (Wackernagel \& Yount, 1998) as a spatial entity rather than to a nation or a community. Refraining from the dispensable on the ground that others should not be forced to refrain from the indispensable, today or in the future, would thereby be an expression of solidarity. Scholz' (2008) concept political solidarity concurred with this view. While civic and social solidarity is based on national, class, or group affiliation, political solidarity is founded on opposition and resistance against social and ecological injustice and degradation of the human value wherever it arises in the world (Scholz, 2008), making for cross-boundary solidarity, compliant with ecological citizenship. In this context, Gould brought to mind the limitations of individuals' as well as groups' solidarity ambit, but also emphasized that there is always "a horizon of possibility where it refers to a disposition that each can have to act in solidarity with some others" (2007, p. 155). Commitment to enhanced justice is the conjunctive element in political solidarity, not, however, implying that the theoretical understanding of justice must be identical. As justice can be related to ecological, economical, as well as social issues, the connection between justice and sustainable development is evident. Deeming solidarity to be a precondition for sustainable development hence means highlighting the significance of a future-dimension as well.

\section{The future-dimension}

Bell (2002) and Hicks (2002) underlined the need to pay attention to the future-dimension in education in times of increasingly rapid change. Hicks (2002) argued that instead of leaving the future to economists, politicians, and multinational companies, we need to explicitly consider how the local and global future relate to each other, and in which direction we want to develop. Knowing which future we desire has a bearing on our current actions. Thus he proposed to train the students in thinking about the future(s) by using the categories possible, probable, and preferable futures. He concurrently conveyed the striking insight that teaching often lacks a future-perspective. The same tendency was observed by Rushkoff (2013) in the whole society of today, and he believed it was caused by the digital communication technique fettering us to several simultaneous NOWs, constantly demanding updating. In combination with the growing individualization, this situation limits our capability of focusing on relations beyond us in time as well as in space (Rushkoff, 2013).

\section{Solidarity and the future-dimension}

Torbjörnsson and Molin (2014) found significant, positive correlations between futureorientation and three aspects of solidarity among Swedish upper secondary school students. Students who frequently thought about the future claimed to be more inclined to take responsibility, also encouraging others to take a solidary responsibility for sustainable development.

Social psychological studies have shown that future-oriented people reflect more over moral issues, and that distance in time greatly affects to what extent individuals are using moral arguments to motivate their actions (Agerström \& Björklund, 2013). Referring to moral values appeared to be more common when motivating future actions than 
forthcoming actions, the significance of moral arguments growing with increasing distance in time (Agerström \& Björklund, 2009, 2013; Eyal, Liberman, \& Trope, 2008). Reflecting on future actions requires abstract thinking, and this activates the individual's moral values (Trope \& Liberman, 2003), while forthcoming actions are more influenced by various "musts," habits, and practical circumstances.

On the background of student groups having different preconditions, a future-dimension might be essential for developing students' environmental moral learning. Training the students to reflect on future consequences of everyday decisions is likely to increase the probability of their spontaneous consideration of long-term consequences when facing moral dilemmas (Agerström \& Björklund, 2013).

\section{Teaching solidarity}

The implication of solidarity has rarely been problematized in studies on solidarity development among students (Sleeter \& Soriano, 2012). It is rather taken for granted, and often refers to a sense of unity and kinship at class or school level. Research has shown that this "internal" solidarity can evolve by developing communication forms that facilitate cooperation (Roth \& Tobin, 2010), strengthening the relations between the students (Beaty-O'Ferrall \& Johnson, 2010; Olitsky, 2011), or by the class acting as agents of change in the local community (Beckett, Glass, \& Moreno, 2012; Boscardin \& Jacobson, 1997; Renner, 2009). Gallay, Flanagan, \& Duo (2011) showed that students' sense of solidarity with their classmates might have a decisive impact on their view of the world. Students from different schools were to take a stance on how leaders and followers should be treated after transformation from dictatorship to democracy in a fictive country. Students specifying solidarity and pride as characteristic of the relations at their school were inclined to promote reconciliation rather than retribution. This pinpointed that solidarity holds a relational value, encompassing different degrees on a scale, and stressed the importance of not coercing solidarity into a specific category at a predefined level.

Research has furthermore manifested the significance of authentic encounters for developing solidarity. DeZeeuw Spencer analysed which teaching that particularly contributed to strengthening the solidarity between members of a culturally heterogeneous student group, and underscored four teaching styles: (1) Self-work means developing a humble attitude towards other opinions by authentic encounters. (2) Care cultivation alludes to teaching situations where caring about nature and other people is prevalent. (3) Rigorous inclusivity summarizes strategies counteracting the building of walls between different groups, exerting a constant vigilance against exclusion of marginalized voices. (4) Hope-focused agency refers to a solution-oriented, future-directed strategy to counteract nihilism, resignation, and frustration. Several students "changed side" during the study, illustrated by the following citation: "I am a hope convert. I've realized that being dismissive of hope is the luxury of the privileged" (DeZeeuw Spencer, 2011, p. 304).

Eilam and Trop (2011) underlined the importance of a multidimensional teaching repertoire. Successful ESD-teaching is characterized by the combination of four learning forms: subject-specific learning (directed towards analysis and rationality), multidisciplinary learning (directed towards system comprehension), multidimensional learning (adding time and spatial dimensions), and emotional learning (including ethical stances and feelings being aesthetically expressed). "Gestaltungskompetenz," an environmental education programme, in which solidarity is explicitly and 
implicitly incorporated as a competence to develop, is an example of such integrative ESD-teaching. Close to $80 \%$ of the students in this programme claimed to have learnt "how to look ahead, understand complex facts in the context of sustainability, work with others as part of an interdisciplinary team on problems of (non-)sustainable development, and evaluate various solutions to problems" (deHaan, 2010, p. 319). A Swedish study showed that geography teaching in upper secondary school mostly lacks such an integrative perspective, the teaching being characterized by an essentialistic subject view, excluding the ethical dimension and the "opportunity to discuss issues concerning solidarity, social justice, equality, ethnicity, leading to the development of a sustainable society mainly being lost" (Molin, 2006, p. 242). Other studies concluded that selective traditions, essentialist, and epistemologically one-dimensional subject-content (Lundqvist, 2009; Östman, 1995; Svennbeck, 2003) dominate science-oriented subjects. Teaching presenting only one perspective may lead to students being socialized into what Munby and Roberts (1998) labelled "intellectual dependence," rather than "intellectual independence." The latter enables the students to embrace different modes of describing reality, and to use several perspectives when discussing ethical considerations, yielding them "reasoning power," thus preparing them for the role as ethical, responsible, and active citizens.

\section{Method}

Students' perceptions of solidarity and future were investigated through interviews. The interview questions encompassed which circumstances and contexts the students linked to solidarity. The future-dimension concerned students' appreciations of how far away the future is, and in what way they thought they would be able to influence the future. An overarching concluding interview question pertained to whether the students perceived that the school's teaching in fact had prepared them sufficiently for discussions about solidarity.

Six pilot interviews formed the basis for the formulations of a semi-structured interview guide. ${ }^{1}$ The analysis was based on 17 qualitative interviews, one being a group interview with four participants, two were pair interviews, and the remaining 14 were individual interviews. Two of the schools were distant and visited within a restricted time-slot, and conducting group and pair interviews in these schools, thus maximized the number of participants. A total of 22 students $(14$ women and 8 men) from five upper secondary schools were interviewed during January to March 2012. The selection of schools was based on the ambition to recruit students from vocational as well as theoretical programmes. A poster with an invitation to participate in an interview study concerning "questions about nature, environment, justice, and the future" was pasted onto notice boards at six upper secondary schools in two larger cities in Middle Sweden. Interviews were booked at respective schools in the order of incoming applications by e-mail. Recruitment was terminated after 22 applications. The interviews were conducted in a separate room at each school. Each interview lasted 30-45 minutes, and each informant received two cinema tickets as recompense. The interviews were recorded, and stored as digital audio files. Interview parts, corresponding to the final analysis categories, were transcribed. Students were anonymized in the results report and were presented by code, specifying gender $(\mathrm{M}=$ male, $\mathrm{F}=$ female $)$, programme $(\mathrm{N}=$ natural sciences, $\mathrm{S}=$ Social sciences, $\mathrm{V}$ $=$ vocational $)$, and serial number $(1-22)$. 


\section{Analysis}

Thematic analysis (Braun \& Clarke, 2006) was used to scrutinize the interviews. The material was first coded into categories, forming the foundation for thematization. Encoding was determined by the theoretical assumption that solidarity might be regarded as an aspect of sustainable development, and is characterized by engagement in social and ecological justice, along with a desire to remove obstacles to such justice wherever the need arises (political solidarity). Solidarity may include individuals and groups, denied their rightful ecological footprint, as well as other species and future generations (ecological citizenship). The objects of solidarity are thereby not predetermined, but are a consequence of the disposition individuals might have to act in solidarity with those to which they assume a relation (Gould, 2007).

The following codes were identified: solidarity, future, justice, sustainable development, and knowledge. Repeated listening to the whole interview material was carried out, transcribing the parts fitting into any of the codes. After careful reading, the material was encoded by using the programme NVivo. Interview quotations, illustrating any aspect of a code, were categorized into this code. In many cases, codes overlapped, resulting in the same quotation being encoded into more than one category.

The next step focused on pinpointing different themes with the two codes solidarity and future. The aim was that within each theme surfacing, the quotations should be characterized by internal homogeneity, while clear and identifiable distinctions, external heterogeneity, should differentiate the different themes within each code (Patton, 2002). This procedure was performed several times, since codes and themes often related to each other in more than one way; and the number of themes was eventually reduced, either because too few data supported them, or because themes that at first appeared different revealed an overlap on essential points. After reduction, each theme represented an instrumental and consequential segment of the design that overall characterized this interview study. Finally, the themes were named and classified, and an analytical interpretation of their significance was completed.

\section{Results}

\section{Solidarity}

The interviews yielded examples of solidarity stretching into the future and to other species. Most students spoke about these aspects without using solidarity as a concept; but the phenomenon solidarity, as defined theoretically, materialized through the students' descriptions of relations between people, and between mankind and nature. Few students stated having encountered the concept solidarity in teaching, and consequently, the foundation for its thematization was deemed insufficient. Two themes that emerged were the foundation for solidarity and inclusiveness.

\section{The foundation for solidarity}

The foundation for solidarity defines the basic rationale for solidarity (Stjernö, 2004). The students expressed a need for increased justice between people as an obvious theme and an articulate incentive for solidarity. The justice theme was split into the sub-categories distributive, juridically intergenerational, and ecological justice. Most answers expressed a wish for increased distributive justice; resource distribution should be changed to diminish poverty, and to equalize the differences between the rich and the poor. A concern 
emerged about development going in the wrong direction as social gaps are expanding. "It feels like when the gaps are increasing, one returns to.../... in the development" (FV4). Associations to a retrogression reoccurred in several answers: "Yes... it's almost like returning to those classes (FS8), it almost begins to look more like the medieval nobility, if continuing like this" (FN6). Presumptions were discerned in that increased gaps were viewed as a historic deviation: "the crack between the poor and the rich constantly increases, making it less equal over time, and that is something that actually is totally wrong, since we're working for more equality" (MS9). Justice was to them not only about resource distribution, but concerned juridical justice as well; all people should have the same rights and opportunities: “... that everyone has the same opportunities, but this can also be seen as equal sharing, that one shares the opportunities" (FN10) and "... like that everybody is living, following the same laws... everybody has a right to the same care, everybody has a right to the same ... well, all that stuff' (FN11). The support of the justice incentive was prevalent, but several students stressed that justice does not mean that everyone should have equal amounts. Education and efforts should, e.g. lead to higher salary, but the differences in salary must be reasonable: “... yeah sure, that some people are a bit better off... someone who has a lot of education, and perhaps is running a successful business... that's one thing, but that some people must have it so terribly bad, that's not okay..." (FN15).

A smaller share of the students extended the foundation for solidarity into encompassing more than distributive justice between people, approaching a deep respect for life as the basic motive for solidarity: "If we go back to the part about nature...//... since we're all living together on our only Earth, we have something in common... life, we've got a life, and that in itself is really... I don't know, we all live very differently, but we're still living our lives... in that sense I can see that we're all human, and we need... but nature too... I don't think all people have a relation to nature... I don't think so" (FN6). The foundation for solidarity thus being broadened opened for intergenerational and ecological justice, encompassing other species than mankind. This actualized the theme about which we include in the circle we show solidarity with.

\section{Inclusiveness}

The students' spontaneous examples of inclusions into their circle of solidarity displayed large spatial and social variations, ranging from team-members, classmates, the population in "this city... this country" (FN6) to "the poor countries" (MS15).

Instead of defining restrictions for which groups that may be included in the solidarity, or motivating why a category potentially may not be included in the solidarity, the students sought clarifications that would facilitate the inclusion of categories they did not have a personal or mutual relation to. Their answers thereby opened for a socially heterogeneous solidarity, without tangible borders. Some answers opened for solidarity with a wider circle of anonymous, more diffusively defined groups, where the motive would not be temporary, but rather linked to long-term structural power relationships "... to feel solidarity with all people, that we who have the opportunity to influence shall influence for those who can't, like the poor, who have no influence" (FN6).

Capability of taking a stance and of identifying oneself with others was underlined as central prerequisites for solidarity: "To at all visualize oneself in someone else's place" (MS9), and "to feel fellowship with others ...//... that one can identify with" (FN6). Although most answers exhibited a great openness concerning who may be included in solidarity, the picture was not unanimous. One student claimed geographical and cultural 
distance to have a bearing: "The further away someone is from one's own relation, the harder I think it is to show solidarity" (MS16). The other answers did not emphasize geographical distance as a hindrance to solidarity. Examples closest to the students appeared to be when people were hit by war, starvation, or nature catastrophes like the earthquake on Haiti: "Wow, what would have happened if I had lost my child, what would have happened if I had lost my house? ...Then you feel that you just wouldn't be able to handle it... of course I must help out." An emotional engagement coupled with a sense of common responsibility was also deemed essential: "... if we have something central to gather around. That way I think that... those who are conscious of the climate changes, the crisis, are able to feel solidarity with each other ...//... I think many want to fight for this, and I think this solidarity is very strong...//... this movement might affect politics very much..." (FN6). This answer opened for the climate threat being regarded as an ethical issue, having direct bearing upon consequences for future generations.

\section{Intergenerational solidarity}

Solidarity with future generations was one of the bedrock reasonings in the original definition of sustainable development (WCED, 1987). This requires ethical considerations whether our current actions are compliant with the needs of future generations. The students had in this regard a tendency to formulate what needs to be done: “...but that's my point, that you must start to care and perhaps start sacrificing a little now, so that those in coming generations don't need to sacrifice too much of their lives and their living standards" (FN6). Several of the interviewed youths conveyed an explicit will to show solidarity with future generations, but also demonstrated an insight into the difficulties of converting this into action today: "One thinks that I live my life now, and I want to live it as well as I can. I don't want to sacrifice things just because four generations later need this and that... I think people aren't patient enough to reflect... we're too busy in our lives, too egoistic" (FN6). This response illustrated a socio-ecological dilemma, pinpointing the conflict of interests between the short-term individual and a long-term societal/ global perspective. In contemplating future generations, the question whether solidarity should comprise other species than humans posed a dilemma.

\section{Solidarity with other species}

Even though most students limited solidarity to humans, there were examples on the solidarity circle being extended to other species. "Yeah well, I'm now thinking about animal cruelty and stuff like that...//... I saw some programme, think it was ducks... like downy anyway... like plucking them alive, and then you feel that's kind of wrong" (FS8). "Solidarity with nature I see more like you must show respect for nature and not destroy ... and protect it... but also to appreciate it and be out there, and use it in the right way" (FN7). Several students maintained a community of interest around environmental and justice issues to be a prerequisite for solidarity, and believed the environment to be superior to human conflicts of interest: "It could be animals too... that you have to think about... as long as you think of other humans... and of other things, I mean everything else that has a life" (MV20). The students suspected that fewer and fewer people spending time in nature might be a stumbling block to feeling solidarity towards nature. "...I think that if you get out a little more in nature, you'll get a better perspective of the world" (FS1). 


\section{The future}

The future is an abstraction without exact contours and given preconditions. Extrapolating current trends and tendencies then seems natural, and conversations about the future might thus contribute to elucidating the presence. Encoding the interviews produced a considerable selection of quotations that expressed the students' thoughts about the future. Beside the answers to direct questions about how they think regarding the future, and how they had encountered teaching about the future, we noticed clauses and reflections from other parts of the interviews where a future tense signalled future. The analysis of this encoding category identified three themes: future agents, future threats, and the future in teaching, each of which comprising a number of "sub-themes."

\section{Future agents}

Future agents, referred to by the students when stating what would affect the future, encompassed school, politicians, and scientists.

The interview answers lacked referrals to political or ideological agents for a sustainable future. Only a few students used the word politics, and when voiced, it was unlinked from sustainable development, or subordinate to science: "I do have hope for the future, and yet I don't... and I have hope for the governmental and politics and all that ... but not when it comes to sustainable development" (FS1). Other quotations exemplified how politicians as a group were exempted from expectations to lead the way to sustainable development: "I think it's about role models as well... politicians are supposed to be role models for the rest of us, and must perhaps start using public transport, and then perhaps other people would follow and do the same as they do" (MV20). "Yes, it's a bit heavy, a bit cussed actually...//... why don't those ... like, the politicians, those who set the rules, do something" (MN13).

Some of the answers revealed that school had made the students aware of their own responsibility towards a future sustainable development: "I don't know how we're going to sort it out then, I think... no, that's how my teachers usually say then... that we are the solution to the problem in the future" (FN7), and: "you're going to have to deal with it yourselves... that's what one's told there" (FV5). Several interviews disclosed that the future-dimension had been rare during education, and the students had not been involved in discussions, where they together with their classmates had been trained to work on different future scenarios. Neither school nor teachers were accredited any prominent role or function as future agents, and some answers revealed that students did not expect teaching to cover issues about our common future: “... and then it's also so that if school would teach [about the future], then everybody would get the same way of thinking." Interviewer: "Is that how it is?" "...Everybody thinks in the same way about how to work out a maths problem ... if school would teach that 'this is how it is' ... then I would probably think that "this is how it is" (MS12). The notion that school teaching offers unambiguous answers, neither possible to interpret differently nor in need of being critically tested, drastically illustrated why this student did not expect to be educated about alternative futures. The future not being accommodated in the education was by the students rationalized as not belonging to any specific subject: "Our common future? No, that never came up. But there's no subject called discussion, so perhaps it's difficult to take it up in biology or something like that" (MS9).

The future agent that most students had faith in was the scientist. Several interviewees revealed confidence that research in natural sciences and technology would lead the way 
to a sustainable future: "That knowledge [about what is required for sustainable development], doesn't it already exist within the areas the scientists are working on?" Interviewer: "What is that?" "It's everything... chemistry, biology, physics" (MS9). A minor part of the students identified themselves as future agents, not primarily by their own driving force, but rather because they felt "pressurized" by their surroundings, i.e. school. It was on the other hand not discerned that students viewed their teachers as future agents; and the future scenario, as judged by the students' recounts of school teaching, appeared to them in several cases rather bleak: "... a little like a horror scenario, I'd say" (FS22). "I have a rather pessimistic view of the future when it comes to nature" (FN6).

\section{Future threats}

The students identified three future threats: climate threat, resource shortage, and social risks.

"So, it (the future) will go under if we don't do anything, kind of... I think it's a bit like that it's been presented in school" (FN7).

A third of the interviewees believed greenhouse gas emissions to be a problem, but the threatening scenario was downplayed, and they did not appear too pessimistic. Some of the students displayed a pronounced frustration over politicians' lack of initiative. The expectation that research in natural sciences, along with technological applications, would yield solutions to the energy problems was widespread.

Reduced biodiversity and forthcoming resource shortage were in some interviews projected as: "The wildlife on earth is busy disappearing" (FS19). One student was concerned about limited oil resources, future lack of food, and less forests to live off: "What's so frightening with the future is that everybody's saying that everything will end... the oil will be finished and all that" (FS11). There was a general concern that leading a good life in the future might be challenging, and several students highlighted the risk of increasing social inequalities. "The rich and the poor, there'll be a big difference; if you make a mistake and become really poor, then that will pave the way for your children... that they too will end up like that" (MV21). Contemplating the risk of unemployment and struggles in making a living led to reflections about the feasibility of starting a family: "Is it really so smart to have children, when the conditions are going to become more and more difficult as we move forward in life" (MV20).

The latter two answers diverged from the average pattern observed in a previous study on youths' deliberations about the future (Hicks, 2002), where pessimism concerning the future was associated with the common future, while the individual future was described in more positive terms. One of the 22 interviewed students in the present study consistently expressed a positive view of the common future, by underscoring democracy and equality, but also technology. "In 2050, then the world will be totally different, then it'll be much more technical ... all countries have more equality... all countries are democratic too. There are no more dictatorships. The world is as it should be, in a way more open, free, and... equal" (MS15). Although concern about future threats did not dominate the students' accounts, it existed as a dormant backstage. "I don't feel bad all the time by thinking about... I don't think about it that often... it's there, in the back of my mind all the time" (FN6). Future threats being so clearly defined as common challenges raised the question whether the students perceived that teaching had prepared them to face the future as a common undertaking, and if so, to what extent. 


\section{The future in teaching}

The two perspectives accounted for in a teaching context were individual future and our common future. "I usually don't think about the world most of the time; I think about how it will be for me" (MV21). This standpoint was expressed by several students, and the individual future was also what the students primarily referred to when reflecting on how they had encountered issues about the future within teaching. Especially students in vocational programmes stressed that the message had been that "Everything is self-determining responsibility," and that the future was about individual choices. "On an individual level sure... a lot, since we are in a vocational programme" (FV2). The most pronounced link to the future in school seemed to be the study and career counsellor: "It's that we've kind of been talking to the career counsellor about our own future. Otherwise we wouldn't have brought it up ..." (MS12). Having focused on the individual level, with no experience of discussing future perspectives in class, had resulted in the students being oblivious of their classmates' notions about the future. With only a few weeks remaining to their baccalaureate at the time of the interviews, a woman professed: "...it feels like everybody is just going to follow their own agenda, not giving a shit about anything else... someone else must deal with that... sure, but everybody is going in their own direction, not like one should be thinking about what happens to others or so" (FS8). Their unfamiliarity with comparing and discussing different future perspectives was evident: "No - we never discussed the future - no" (MS9). "Gee... we don't talk much about the future except for our own" (FN17). Some answers clearly disclosed that they did not expect teaching to include matters about the common future, since no specific subject covered the future: "Nah ...(laughter), we never had that, I can't imagine in which lesson that would happen" (MN14).

The students had a complex and multifaceted picture of the future. The climate threat was experienced as real but not paralyzing; and the students believed research in natural sciences would provide a solution, rather than politicians. Our common future had obviously not been a salient component of teaching, and taking a stance on the matter of solidarity with future generations was not common practice to these students.

\section{Discussion}

Most students in the present study were unacquainted with the concept of solidarity.

Inasmuch as they perceived solidarity being included in the teaching, they mainly associated it with civic solidarity in a historical context. Notwithstanding, many students expressed inclination and readiness to act in solidarity in order to contribute to social and ecological justice, also in relation to future generations. With the theoretical framework of the present study in mind, we interpreted this as a propensity for political solidarity (Scholz, 2008), and to be in line with environmental citizenship (Dobson, 2003). The interviews furthermore disclosed that the students were unaccustomed to discussing alternative futures in terms of possible, probable, and preferable futures, and they viewed the future as an individual rather than a common challenge. The students showed confidence in natural scientists solving the problems of the future. They did not, however, have much faith in politicians in that sense, and they were also unable to foresee school, teachers, or students playing an active role. This manifested a lack of future-dimension in education, as previously suggested by Hicks (2002). 
What yields particular merit to the present study is the problematization of a sorely under-investigated section within ESD: How do students perceive the future-dimension and the value solidarity in teaching? Did the education include reflecting and discussing these issues?

The interviews proffered unexpected insights into how youths perceive matters concerning the future in relation to the assignments of the school and the purpose of education, augmenting the understanding of the current preconditions for environmental moral learning.

The posters produced to attract students for the interviews stated that the study concerned questions about nature, environment, and justice, and that these questions related to the future. It cannot be ruled out that the formulation attracted students with a particular strong interest in these matters. The interviewees were nonetheless perceived as a heterogeneous group, displaying diverse lines of interest.

Twenty-two students did not allow for generalization of how students as a group reason about the future. However, in combination with a recent study (Torbjörnsson \& Molin, 2014), the present investigation forms a solid foundation for further research on solidarity and its link to the future in teaching, the impact of limited presence of these matters in teaching on students' environmental moral learning being of particular concern. Calling attention to the interviewed students' claims to have experienced neither teaching nor discussions about alternative future scenarios will hopefully incite teaching about the future-dimension and the value solidarity, truly incorporating them into the curriculum.

\section{The solidarity-dimension}

Approximately half of the interviewed students were unfamiliar with the meaning of the word solidarity. The most common association to solidarity was in a historic context, with instituting the tax-financed welfare state being what defined the foundation for solidarity, and the majority of the nation constituting the inclusion category, an interpretation corresponding to civic solidarity (Scholz, 2008). The student examples confirmed the conclusions of the meta-analysis by Eilam and Trop (2011): ESD-teaching requires an emotional dimension in order to achieve its goals. The openness concerning with whom or with which the students were capable of showing solidarity, expressed a disposition similar to Gould's (2007): everybody's potential to be solidary to some others. Since the student engagement in social justice was not limited to predefined categories, it concurred with Gould's (2007) definition of transnational solidarities. The community values most significant for solidarity were not based on national or social affiliation, but on a common view on matters of importance, i.e. justice, environmental respect, and that we "have something in common... life" (FN6). With this in mind, it is quite logical to view this form of solidarity as an expression of ecological citizenship (Dobson, 2003).

Solidarity was by the interviewees proclaimed to be a value encompassing relations between individuals and groups, not socially or spatially predetermined, but connected by a common desire to increase social and ecological justice. As a rule, solidarity may be extended to future generations, and as an exception, also to other species. The students articulated no pronounced resistance towards including other species in a solidarity context. Whether this was a result of a deliberate ethical stance, or the students being unaccustomed to the solidarity concept, could not be determined. That question alone manifested that inclusivity of solidarity is a 
momentous, relevant aspect to consider when making didactic ${ }^{2}$ choices, aiming at developing students' environmental moral learning in ESD.

Altogether, the present research strengthens the arguments for solidarity being a fundamental prerequisite for sustainable development, and hence solidarity must be given a prominent position in ESD.

\section{The future}

At the time of the interviews, the 22 students (18-19 years old) had been subjected to almost 12 years of comprehensive and upper secondary school education, with only 3-4 months remaining to baccalaureate.

The most striking interview-result was that all the interviewees agreed with teaching about the future being a rare, or non-existent, component in teaching. Some answers clearly expressed that the students did not anticipate the future to be brought up in teaching since no subject contained the future as a component; they considered teaching of matters where knowledge could not be ascertained not to be the school's assignment. These responses suggested that the students primarily linked teaching to questions with unambiguous answers - perhaps representing what they mainly had encountered in school teaching. In that sense, this study corroborated the epistemological one-sidedness and absence of moral dimensions revealed in earlier analyses of science teaching (Lundqvist, 2009; Svennbeck, 2003; Östman, 1995) and geography teaching (Molin, 2006). The interviews furthermore conveyed that listening to and participating in discussions on alternative modes of thinking around futures had not been part of the students' training. When taking a closer look, a student role appeared, signalizing low political competence in combination with being unaccustomed to comprehending and debating with voices that diverge among the fellows in class. With teaching frequently presenting one-dimensional explanations for social problems, it was not surprising that a majority of the 22 interviewed students did not perceive school as a creative future-workshop.

In the dialogues about the future, the students were noticeably concerned about the future. They did however not express angst, but rather an explicit desire to contribute in that the threats would not be actualized. The desire was however not effectuated in their minds. It was more "this is how it should be" and less "this is what I do to make it the way it should be." Instead, most of the students distanced themselves from future risks and threats in various ways, and only two of the interviewees explicitly included themselves when talking about future risks of unemployment and increasing income gaps. The school's contribution to preserving and refining the students' potential (from will to action), shaping them into presumptive participants instead of just spectators, had evidently been limited.

The conclusive interview question concerned their opinion about how school had prepared them for participating in "a conversation like this, about justice, the future, and sustainable development." With the exception of four students, two associating to a role-play about climate and two others who had participated in a study trip to a school in India, the students conveyed a fairly unanimous picture of teaching not addressing these issues in any noticeable way. "... That's more stuff you have looked up yourself... it's never something that anyone (teacher) has dealt with in depth... no" (FV4)... "But I think that might depend a little on them (the teachers) not being sufficiently informed to be able to inform us... a little bit like they don't want to go into things they don't know" (FV5). 


\section{Conclusion}

Teaching being devoid of engagement in solidarity and the future appeared to encompass only the three years in upper secondary school as judged by the students' answers, and might be explained by the fact that few of the interview participants had studied geography, the sole subject where ethical considerations in connection with sustainable development is incorporated into the syllabus. The Swedish steering documents make it clear, however, that all teachers carry the responsibility to teach in a manner that convinces the students to develop a sense of the value solidarity and an ability to reflect on what a sustainable future entails.

The students mostly constructed their views of the future by extrapolating today's trends, rather than by drawing conclusions from democratic negotiations between different public interests. So far as dark future scenarios were communicated, the students referred to these as a picture conveyed by the school. Hence, it appeared that the didactic advice on possible, probable, and preferable futures, proffered by Hicks' (2002), had had no sizeable impact. Several students nonetheless pointed out that teaching had imparted a responsibility to form a good future, indicating a didactic ambition in school, although too weak to bring hope for the future, something research has disclosed that purposeful teaching about the future is able to do (Hicks, 2002; Holden, 2007; Ojala \& Rikner, 2010). The International Civic and Citizenship Study (ICCS) study (Skolverket, 2010) has established that Swedish students relatively strongly support democratic values, i.e. equality, tolerance, and freedom of speech. Other surveys have also shown that Swedish students in upper secondary school in general show positive attitudes to solidarity (Torbjörnsson, 2011; Torbjörnsson \& Molin, 2014). To what extent this is a result of the socialization brought about by teaching, and to what extent it might be explained by primary socialization, could not be concluded in the present study. The current strong position of democratic values and solidarity among Swedish students is indeed worthy of nurturing, and needs to be contemplated on the background of the antidemocratic powers presently growing strong in the students' surroundings. Assuring that didactic choices are founded on the existing community of values, and allowing the values of importance to the students to be important also in the teaching, means taking students seriously.

The connotation of solidarity is not fixed but needs to be problematized in each new context. Identifying with various religious, ethnic, and national communities has become increasingly important to young people's identity, and consequently we need to stress the momentousness of global citizenship, not allowing it to become elusive.

The involvement in cross-border solidarity and social justice expressed by the youth in our study lends hope in a time characterized by increasing gaps and social, ethnical, and religious tensions. As this involvement is stronger in future-oriented individuals (Torbjörnsson \& Molin, 2014), highlighting the future-dimension in geography teaching becomes even more urgent. Moreover, further research is required in order to clarify how education may reinforce the linkage between a future-orientation on the one hand, and solidarity, democracy, and other values emphasized by the steering documents on the other.

\section{Disclosure statement}

No potential conflict of interest was reported by the authors.

\section{Funding}

Funded by the Swedish Research Council [grant number 2010-5687]. Preconditions of environmental moral learning within education for sustainable development: A multidisciplinary study of young Swedes attitudes, commitments and actions. 


\section{Notes}

1. See Appendix 1.

2. Didactic refers to the why-, what-, and how-questions in teaching. Placing the why-question first emphasizes the continuous need of reassessing the purpose of the teaching.

\section{References}

Agerström, J., \& Björklund, F. (2009). Moral concerns are greater for temporally distant events and are moderated by value strength. Social Cognition, 27, 261-282. doi:10.1521/soco.2009.27.2.261

Agerström, J., \& Björklund, F. (2013). Why people with an eye toward the future are more moral: The role of abstract thinking. Basic and Applied Social Psychology, 35, 373-381. doi:10.1080/ 01973533.2013.803967

Beaty-O'Ferrall, M. E., \& Johnson, F. W. (2010). Using supportive team building to promote improved instruction, student achievement, and collaboration in an urban professional development school. School-University Partnerships, 4, 56-64.

Beckett, L., Glass, R. D., \& Moreno, A. P. (2012). A pedagogy of community building: Re-imagining parent involvement and community organizing in popular education efforts. Journal of the Association of Mexican American Educators, 6, 5-14.

Bell, W. (2002). Foreword. Preparing for the future. In D. Hicks (Ed.), Lessons for the future. New York: Routledge Falmer.

Boscardin, M. L., \& Jacobson, S. (1997). The inclusive school: Integrating diversity and solidarity through community-based management. Journal of Educational Administration, 35, 466-476. doi:10.1108/09578239710184600

Braun, V., \& Clarke, V. (2006). Using thematic analysis in psychology. Qualitative Research in Psychology, 3, 77-101. doi:10.1191/1478088706qp063oa

deHaan, G. (2010). The development of ESD-related competencies in supportive institutional frameworks. International Review of Education/Internationale Zeitschrift für Erziehungswissenschaft, 56, 315-328. doi:10.1007/s11159-010-9157-9

DeZeeuw Spencer, J. (2011). Strengthening the SEAMS between us: Sustainable, equitable, actualized meaning-making and solidarity. Ann Arbor: Prescott College.

Dobson, A. (2003). Citizenship and the environment. Oxford: Oxford University Press.

Dobson, A. (2007). Environmental citizenship: Towards sustainable development. Sustainable Development, 15, 276-285.

Eilam, E., \& Trop, T. (2011). ESD pedagogy: A guide for the perplexed. Journal of Environmental Education, 42, 43-64. doi:10.1080/00958961003674665

Eyal, T., Liberman, N., \& Trope, Y. (2008). Judging near and distant virtue and vice. Journal of Experimental Social Psychology, 44, 1204-1209. doi:10.1016/j.jesp.2008.03.012

Gallay, L., Flanagan, C. A., \& Duo, S. (2011). Retribution or reconciliation: Young Americans' attitudes toward peaceful transitions of power. Youth \& Society, 43, 568-582.

Gould, C. C. (2007). Transnational solidarities. Journal of Social Philosophy, 38, 148-164. doi:10.1111/j.1467-9833.2007.00371.x

Hicks, D. (2002). Lessons for the future: The missing dimension in education. London/New York: Routledge/Falmer.

Holden, C. (2007). Young people's concerns. In D. Hicks \& C. Holden (Eds.), Teaching the global dimension. London: Routledge.

Leiserowitz, A. A., Kates, R. W., \& Parris, T. M. (2006). Sustainability values, attitudes, and behaviors: A review of multinational and global trends. Annual Review of Environment and Resources, 31, 413-444.

Lundqvist, E. (2009). Undervisningssätt, lärande och socialisation: Analyser av lärares riktningsgivare och elevers meningsskapande i NO-undervisning. Uppsala: Acta Universitatis Upsaliensis.

Molin, L. (2006). Rum, frirum och moral: En studie av skolgeografins innehållsval. Uppsala: Department of Social and Economic Geography, Uppsala University.

Munby, H., \& Roberts, D. (1998). Intellectual independence: A potential link between science teaching and responsible citizenship. In D. Roberts \& L. Östman (Eds.), Problems of meaning in science curriculum (pp. 101-114). New York: Teachers College Press.

Ojala, M., \& Rikner, A. (2010). Att hantera det ambivalenta : unga vuxnas attityder och beteende gällande energisparande $i$ hemmet. Örebro: Centrum för urbana och regionala studier, Örebro universitet. 
Olitsky, S. (2011). The role of fictive kinship relationships in mediating classroom competition and supporting reciprocal mentoring. Cultural Studies of Science Education, 6, 883-894. doi:10.1007/s11422-011-9363-1

Patton, M. Q. (2002). Qualitative evaluation and research methods. Thousand Oaks, London, New Delhi: Sage Publications.

Renner, A. (2009). Teaching community, praxis, and courage: A foundations pedagogy of hope and humanization. Educational Studies, 45, 59-79. doi:10.1080/00131940802527209

Roth, W.-M., \& Tobin, K. (2010). Solidarity and conflict: Aligned and misaligned prosody as a transactional resource in intra- and intercultural communication involving power differences. Cultural Studies of Science Education, 5, 807-847. doi:10.1007/s11422-010-9272-8

Rushkoff, D. (2013). Present shock. New York: Penguin Group.

Scholz, S. J. (2008). Political solidarity. University Park: Pennsylvania State University Press.

Skollag. (2010:800). Skollagen. Stockholm: Sveriges Riksdag.

Skolverket. (2010). Morgondagens medborgare. ICCS 2009: svenska 14-åringars kunskaper, värderingar och deltagande i internationell belysning (Vol. 345). Stockholm: Skolverket.

Skolverket. (2011a). Curriculum for the upper secondary school. Retrieved December 27, 2013, from http://www.skolverket.se/publikationer?id=2975

Skolverket. (2011b). Curriculum, compulsory school, preschool class, recreation centre, in English. Stockholm: Skolverket.

Skolverket. (2011c). Syllabus geography 1. Retrieved July 18, 2015, from http://www.skolverket. se/laroplaner-amnen-och-kurser/grundskoleutbildning/grundskola/geografi.

Sleeter, C. E., \& Soriano, E. (2012). Creating solidarity across diverse communities: International perspectives in education. New York: Teachers College Press.

Stjernö, S. (2004). Solidarity in Europe: The history of an idea. Cambridge: Cambridge University Press.

Svennbeck, M. (2003). Omsorg om naturen: Om NO-utbildningens selektiva traditioner med fokus på miljöfostran och genus. Uppsala: Acta Universitatis Upsaliensis.

The Swedish National Commission for UNESCO. (2014). Utbildning för hallbar utveckling. Retrieved January 2, 2014, from http://www.unesco.se/utbildning/utbildning-for-hallbarutveckling/

Tilbury, D. (2012). Learning to connect: Reflections along a personal journey of education and learning for a sustainable future in the context of Rio + 20. Journal of Education for Sustainable Development, 6, 59-62. doi:10.1177/097340821100600112

Torbjörnsson, T. (2011). En för alla - Alla för naturen. Licentiatavhandling. Uppsala: Forskarskolan i Geografi, Uppsala Universitet.

Torbjörnsson, T., \& Molin, L. (2014). Who is solidary? A study of Swedish students' attitudes towards solidarity as an aspect of sustainable development. International Research in Geographical and Environmental Education, 23, 259-277. doi:10.1080/10382046.2014.886153

Trope, Y., \& Liberman, N. (2003). Temporal construal. Psychological Review, 110, 403-421. doi:10.1037/0033-295X.110.3.403

UN. (2000). The United Nations millennium declaration. New York: United Nations.

Wackernagel, M., \& Yount, J. D. (1998). The ecological footprint: An indicator of progress toward regional sustainability. Environmental Monitoring and Assessment, 51, 511-529.

Wals, A. (2009). A mid-DESD review: Key findings and ways forward. Journal of Education for Sustainable Development, 3, 195-204. doi:10.1177/097340820900300216

WCED. (1987). Our common future. Nairobi: UNEP.

Östman, L. (1995). Socialisation och mening: No-utbildning som politiskt och miljömoraliskt problem. Uppsala/Stockholm: Almqvist \& Wiksell. 


\section{Appendix 1. Interview Guide}

Can you tell me what you think of when you hear the expression SUSTAINABLE DEVELOPMENT?

What is it that shall be sustainable?

In what context have you encountered the expression sustainable development?

How do we notice if the development is not sustainable?

Can you give examples of skills that are important for sustainable development?

What is an environmental problem?

Why do we have environmental problems?

Where does the responsibility lie?

How have you experienced education in/about sustainable development?

Do you have suggestions for how school can work with sustainable development issues?

NATURE - What does nature mean to you? How does it feel to be in nature?

Do you have any special memories - of places, or of experiences?

What is your view on the relationship between mankind and nature in general?

Is there anything you would change in the relationship?

How have you faced nature in your education?

SOLIDARITY - What is solidarity?

What context do you associate with solidarity?

What can cause us to show solidarity?

With whom can we be solidary?

Are we moving towards more or less solidarity?

How have you met solidarity in your education?

JUSTICE - What does it mean to you?

When is justice important?

Are there different ways of looking at justice? Examples?

How have you worked with justice in school?

What do you think about the increasing income inequality in most countries in the world?

Is there a problem? - Why?/Why not? How can the problem be solved? - Where is the responsibility?

FUTURE - How do you look upon the future?

How far away is the future?

How can you influence the future?

How has the future-concept been approached in teaching during your 12 years of education?

CONCLUSIVE QUESTION - This conversation we just had on sustainable development, nature, solidarity, justice, and the future; how do you think your school experience/your education has prepared you to carry out such a conversation? 